\title{
Adsorption of dissolved free amino acids on colloidal DOM enhances colloidal DOM utilization but reduces amino acid uptake by orders of magnitude in marine bacterioplankton
}

\author{
Stefan Schuster ${ }^{1}$, Jesus Maria Arrieta ${ }^{2}$, Gerhard J. Herndl ${ }^{2, *}$ \\ 'Institute of Zoology, University of Vienna, Althanstr. 14, A-1090 Vienna, Austria \\ ${ }^{2}$ Dept of Biological Oceanography, Netherlands Institute for Sea Research (NIOZ), PO Box 59, 1790 AB Den Burg, Texel, \\ The Netherlands
}

\begin{abstract}
In an attempt to quantify abiotic adsorption of easily metabolizable dissolved free amino acids (DFAA) to colloidal dissolved organic matter (CDOM) in the sea, laboratory experiments were performed using dextran of various molecular size ranging from 4.4 to $2000 \mathrm{kDa}$ or phytoplanktonderived CDOM $(>1 \mathrm{kDa})$ as model CDOM, and leucine or a DFAA mixture. Abiotic leucine adsorption to dextran was found to be independent of the molecular size of the dextran. Adsorption of leucine to dextran and phytoplankton-derived CDOM was saturated at $\sim 7.5 \mathrm{nmol} \mathrm{mg}^{-1}$ dextran-C; other DFAA species leached higher sâturating concentrations (maximum: scrinc, $48.6 \mathrm{nmol}^{\mathrm{mg}^{-1}}$ dextran-C). Adsorption of DFAA to dextran and phytoplankton-derived CDOM led to an approximately 3 times more efficient utilization of dextran and CDOM by marine bacterioplankton than colloidal matter to which no DFAA were adsorbed. Bacterial uptake of CDOM-adsorbed leucine, however, was reduced by 2 to 3 orders of magnitude as compared to the uptake of 'truly' free (non-adsorbed) leucine offered simultaneously at the same concentration. This finding might also be relevant for bacterial production measurements if leucine or thymidine are used as a tracer in colloidal-matter-rich micro-environments such as marine snow. All the CDOM-adsorbed DFAA (except glycine and threonine) were detectable without prior hydrolysis by o-phthalaldialdehyde (OPA) derivatization in the HPLC. Adsorption of labile DFAA on otherwise refractory CDOM also has important implications for the biogeochemical flux of CDOM by forming 'semi-labile' molecules which are more readily degradable by bacterioplankton and thereby reducing the flux of CDOM to the deep ocean.
\end{abstract}

KEY WORDS: Colloidal matter - Dissolved free amino acids - Leucine Bacterioplankton - Dissolved organic matter Bacterial uptake Bacterial production measurements

\section{INTRODUCTION}

Bacterioplankton are the principal consumers of dissolved organic matter (DOM) in the ocean (Azam \& Cho 1987). This DOM can be taken up without prior cleavage by bacteria if the molecular weight of the DOM is below 600 (Gottschalk 1986). If the molecules are larger they have to be cleaved by bacterial ectoenzymes embedded in the capsular membrane or the periplasmatic space prior to the uptake (Gottschalk

·Addressee for correspondence. E-mail: herndl@nioz.n1
1986). Nevertheless, it has been shown recently that marine bacterioplankton can utilize high molecular weight material more rapidly than the DOM fraction $<1 \mathrm{kDa}$ (Amon \& Benner 1994, 1996). In their size-reactivity model, Amon \& Benner proposed a gradual transformation from large, labile molecules to small, refractory DOM. While the marine bulk DOM fraction $<1 \mathrm{kDa}$ might be relatively refractory compared to larger molecules, there is a small pool of low molecular weight DOM such as dissolved free amino acids (DFAA) and monomeric carbohydrates which are taken up efficiently by bacterioplankton and, owing to 
their low concentrations, turnover times are short (generally <1 d) (Fuhrman \& Ferguson 1986, Fuhrman 1987, Suttle et al. 1991, Rich et al. 1996). It is well documented that bacterioplankton can cover most of their carbon and nitrogen demand by the uptake of DFAA released by phytoplankton (Jørgensen 1987, Keil \& Kirchman 1991b, Ducklow et al. 1993, Jørgensen et al. 1993, Kirchman et al. 1993, Middelboe et al. 1995).

Abiotic alterations of specific compounds of the DOM might change the availability for bacterioplankton. As shown by Keil \& Kirchman $(1993,1994)$ labile proteins become refractory over time. This process is significantly enhanced by radiation, especially in the ultraviolet (UV) range (300 to $400 \mathrm{~nm}$ ) (Keil \& Kirchman 1994, I. Obernosterer, B. Reitner \& G. J. Herndl unpubl., C. Pausz \& G. J. Herndl unpubl.), while originally refractory DOM becomes labile upon UV exposure (Lindell et al. 1995, 1996, Wetzel et al. 1995. Granéli et al. 1996, Kaiser \& Herndl 1997, Reitner et al. 1997). However, not only light alters the availability of labile DOM. It has been shown that labile DOM also becomes refractory due to sorption processes in sediments (Keil et al. 1994, Hedges \& Keil 1995).

According to Gustafsson \& Gschwend (1997) 'colloidal matter is any constituent that provides a molecular milieu into and onto which chemicals can escape from the bulk aqueous solution, while its vertical movement is not significantly affected by gravitational settling. ' Colloidal dissolved organic matter (CDOM) is an efficient sorption site for charged molecules such as metals or radionuclides (Baskaran \& Santschi 1993, Martin et al. 1995, Moran et al. 1996). In the aquatic environment significant amounts of CDOM are produced during the decay of phytoplankton blooms (Kepkay et al. 1993, Guo et al. 1994, Kepkay 1994, Wells \& Goldberg 1994, Veronclark et al. 1995), by bacterioplankton (Tranvik 1993, Heissenberger \& Herndl 1994, Stoderegger \& Herndl in press) and by chemical reactions between different groups of molecules (Gustafsson \& Gschwend 1997). This CDOM might serve as an important food source for protists (Sherr 1988, Tranvik 1994). Due to the adsorption of labile molecules on CDOM, this CDOM might become a more attractive nutrient source, leading to enhanced mineralization

In our study we tested the hypothesis that CDOM efficiently adsorbs labile molecules in seawater, resulting in enhanced utilization of the CDOM by bacteria while the labile, adsorbed component is taken up less efficiently. Using dextran of various molecular sizes or the colloidal fraction of the photosynthetic extracellular release (PER) as model CDOM, and leucine or a DFAA mixture as the labile component, we determined the utilization efficiency of the CDOM and the adsorbed leucine or DFAA mixture. Thus, in other words, we investigated the importance of CDOM as an abiotic competitor with bacterioplankton for DFAA.

\section{MATERIALS AND METHODS}

Adsorption efficiency of leucine to dextran. The adsorption efficiency of $\left[{ }^{14} \mathrm{C}\right.$ ]leucine [Amersham; specific activity $\left.(\mathrm{SA})=319 \mathrm{mCi} \mathrm{mmol}^{-1}\right]$ to unlabeled dextran (Sigma Chemicals) of various molecular weight was determined in artificial (Parsons et al. 1984) and in aged (for $3 \mathrm{wk}$ at $20^{\circ} \mathrm{C}$ in the dark) $0.2 \mu \mathrm{m}$ filtered seawater (Millipore; polycarbonate) collected from the oligotrophic Mediterranean Sea off Villefranche-surMer (France). Aged $0.2 \mu \mathrm{m}$ filtered or artificial seawater $(48 \mathrm{ml})$ was transferred into a dialysis tube (Spectrapor; $1000 \mathrm{MW}$ cut off, pre-treated according to the recommendations of the manufacturer, see also Herndl et al. 1993) and $1 \mathrm{ml}$ of dextran (prepared in HPLC grade water (Merck); conc. of the stock solution: $1 \mathrm{mg}$ $\mathrm{C} \mathrm{ml}^{-1}$ ] and $1 \mathrm{ml}$ of leucine (stock solution: $68.5 \mathrm{nmol}$ $\mathrm{ml}^{-1},\left[^{14} \mathrm{C}\right.$ leu:cold leu $\left.=2: 3\right)$ added. The dialysis tube was suspended in $950 \mathrm{ml}$ aged or artificial seawater, placed on a magnetic stirrer and held at $20^{\circ} \mathrm{C}$. The time course of the radioactivity detectable outside the dialysis tube was followed over a period of $6 \mathrm{~h}$ by transferring $1 \mathrm{ml}$ subsamples of the water in the jar into a scintillation vial and adding $8 \mathrm{ml}$ of scintillation cocktail (Insta-Gel, Canberra Packard) as described in more detail below. After subsampling, the water was replaced. The experiments were performed with dextran of 8 different molecular weights (from 4.4 to $2000 \mathrm{kDa}$ ).

In order to calculate the adsorption of leucine to dextran over time, dialysis experiments were also run containing exactly the same concentration of $\left[{ }^{14} \mathrm{C}\right]$ leucine but no dextran. From the total number of disintegrations per minute (DPM) detected in the water in which the dialysis tube containing only $\left[{ }^{14} \mathrm{C}\right]$ leucine was suspended, the DPM detected in the surrounding water containing the dialysis tube filled with $\left[{ }^{14} \mathrm{C}\right.$ leucine and dextran was subtracted and converted to nmol leucine adsorbed per mg dextran-C.

Adsorption efficiency of a DFAA mixture to dextran. In addition to the above adsorption experiments with leucine, a DFAA mixture (Sigma Chemicals) was used in one experiment consisting of 2 replicates; the DFAA mixture was composed of 17 amino acid species. To 11 of artificial seawater, $748.55 \mathrm{nmol}^{-1}$ of the DFAA mixture (final conc.) and $2.32 \mathrm{mg}$ dextran $\mathrm{l}^{-1}$ (or $1 \mathrm{mg}$ dextran- $\mathrm{C}^{-1}, 70 \mathrm{kDa}$ ) were added; this was incubated at $20^{\circ} \mathrm{C}$ in the dark for $5 \mathrm{~h}$, filtered through an Amicon ultrafiltration system with a polysulfone cartridge (molecular weight cut-off of $30 \mathrm{kDa}$ ) at low pressure and flushed 3 times with $1 \mathrm{l}$ of artificial seawater in order to remove the non-adsorbed DFAA. The reser- 
voir and the cartridge of the ultrafiltration system were pre-cleaned and conditioned before the experiment by flushing with at least 51 of Milli-Q water, circulating $0.05 \mathrm{M} \mathrm{NaOH}$ for at least $30 \mathrm{~min}$ and flushing again with 51 Milli-Q water. Subsamples $(10 \mathrm{ml})$ for amino acid analyses (described below) were taken from the filtrate and the water retained by the cartridge before and after the adsorption experiments to estimate the concentrations of DFAA adsorbed to dextran.

Bacterial growth on non-adsorbed leucine and dextran compared with dextran-bound leucine as substrate. Experiments on the bacterial utilization of leucine adsorbed to dextran were performed; control experiments were run using free dextran and leucine, respectively, at the same concentrations as bound. $\left[{ }^{14} \mathrm{C}\right]$ leucine adsorbed to dextran was produced in the same way as described above using unlabeled dextran of $70 \mathrm{kDa}$. Based on the radioactivity measurements it was calculated that $9.58 \mathrm{nmol}$ leucine was adsorbed per mg dextran-C. Thereafter, stocks of free leucine and dextran were prepared at concentrations of $9.58 \mathrm{nmol} \mathrm{ml} \mathrm{m}^{-1}$ and $1 \mathrm{mg}$ dextran-C $\mathrm{ml}^{-1}$, respectively. Seawater cultures with 3 different treatments were established by adding either $20 \mathrm{ml}$ of the stock solution of leucine or dextran or the corresponding amount of leucine adsorbed to dextran to $950 \mathrm{ml}$ of double $0.2 \mu \mathrm{m}$ filtered (Millipore; polycarbonate) aged seawater. Subserguently; $50 \mathrm{ml}$ of $0.8 \mu \mathrm{m}$ filtered seawater were added to each of the 3 treatments. At various time intervals samples were withdrawn from the seawater cultures, which were held at $20^{\circ} \mathrm{C}$ in the dark. On subsamples of the 3 different treatments, bacterial abundance and $\left[{ }^{3} \mathrm{H}\right]$ thymidine incorporation were determined as described below.

Bacterial uptake of non-adsorbed versus dextranadsorbed leucine offered simultaneously. In another set of seawater cultures, $50 \mathrm{ml}$ of $0.8 \mu \mathrm{m}$ filtered and concentrated ( $\sim 10$ times) natural bacterial consortia were inoculated in $950 \mathrm{ml}$ double $0.2 \mu \mathrm{m}$ filtered aged seawater amended with $1 \mathrm{ml}$ of $\left[{ }^{14} \mathrm{C}\right]$ leucine bound to dextran (stock solution: $9.58 \mathrm{nmol}$ leucine $\mathrm{mg}^{-1}$ dextran-C $\mathrm{ml}^{-1}$ ) and $1 \mathrm{ml}$ of ${ }^{3} \mathrm{H}$-lleucine $(\mathrm{SA}=125 \mathrm{Ci}$ $\mathrm{mmol}^{-1} ; 9.58 \mathrm{nmol} \mathrm{m} \mathrm{m}^{-1}$ ). Thus, exactly the same concentration of dextran-bound and non-adsorbed leucine was added to triplicate seawater cultures using aged seawater. The natural bacterial community was concentrated by filtering $1 \mathrm{l}$ of $0.8 \mu \mathrm{m}$ filtered freshly collected seawater onto a $0.2 \mu \mathrm{m}$ polycarbonate filter (Millipore; $47 \mathrm{~mm}$ filter diam.) and rinsing of the bacteria collected on the filter with $50 \mathrm{ml}$ of the filtrate. The seawater cultures were incubated for $90 \mathrm{~min}$ at room temperature, which was close to in situ temperature. Within the 90 min incubation period, 8 subsamples were taken from each culture to determine bacterial abundance and uptake of dextran-bound $\left[{ }^{14} \mathrm{C}\right]$ leucine and free $\left[{ }^{3} \mathrm{H}\right]$ leucine as described below. In preliminary experiments with natural bacterial assemblages, uptake rates; of $\left[{ }^{14} \mathrm{C}\right]$ leucine were compared with $\left[{ }^{3} \mathrm{H}\right]$ leucine uptake rates; no significant difference was found.

Bacterial utilization of phytoplankton-derived CDOM and adsorbed leucine. A Chaetoceros muelleri culture was grown in 21 of $0.2 \mu \mathrm{m}$ filtered (Millipore; polycarbonate), autoclaved $\mathrm{f} / 2$ medium (Parsons et al. 1984) at an irradiance of $\sim 100 \mu \mathrm{E} \mathrm{m}^{-2} \mathrm{~s}^{-1}$ (12 h light: $12 \mathrm{~h}$ dark cycle, white cool lamps) at $18^{\circ} \mathrm{C}$. Subsamples of $10 \mathrm{ml}$ were taken once a day to measure the optical density at $550 \mathrm{~nm}$ in a spectrophotometer. At the onset of the exponential growth and in the late exponential phase the culture was amended with $4 \mu \mathrm{Ci}$ of $1^{14} \mathrm{C}$ ssodium bicarbonate. At $24 \mathrm{~h}$ after the second labeling, the culture was filtered onto a Whatman $\mathrm{GF} / \mathrm{F}$ filter, the filtrate was acidified to $\mathrm{pH}<2$ with $2 \mathrm{~N}$ $\mathrm{HCl}$ and bubbled with $\mathrm{N}_{2}$ for $24 \mathrm{~h}$ and the radioactivity of the $\left[{ }^{14} \mathrm{C}\right] \mathrm{PER}$ was measured in $2 \mathrm{ml}$ subsamples with $8 \mathrm{ml}$ scintillation cocktail (Insta-Gel) added. Subsequently, the $\mathrm{pH}$ of the filtrate was adjusted to the original $\mathrm{pH}$ of 8.2 with $1 \mathrm{~N} \mathrm{NaOH}$ and $200 \mathrm{ml}$ portions of the $\left[{ }^{14} \mathrm{C}\right] \mathrm{PER}$ were transferred to dialysis tubes, with a molecular weight cut off of $1 \mathrm{kDa}$ suspended in $2 \mathrm{l}$ of artificial seawater and placed on a magnetic stirrer at room temperature to remove all the phytoplanktonderived PER $<1 \mathrm{kDa}$. The artificial seawater in which the dialysis tubes were suspended was replaced every $2 \mathrm{~h}$ for a total period of $24 \mathrm{~h}$.

Thereafter, a mixture of unlabeled leucine and $\left[{ }^{3} \mathrm{H}\right]$ leucine (final conc. $147 \mathrm{nmol}^{-1}$ ) was added to each of the 3 dialysis tubes each containing $200 \mathrm{ml}$ of the $\left[{ }^{14} \mathrm{C}\right] \mathrm{CDOM}$ (CDOM $>1 \mathrm{kDa}$ ), and the dialysis procedure was repeated as described above for 6 to $8 \mathrm{~h}$. At 30 to $60 \mathrm{~min}$ intervals, $2 \mathrm{ml}$ subsamples were taken from the artificial seawater in which the dialysis tubes were suspended, the radioactivity was assessed and the entire volume of the artificial seawater was replaced. The dialysis procedure was stopped after 6 to $8 \mathrm{~h}$ when significant $\left[{ }^{3} \mathrm{H}\right]$ radioactivity was no longer detectable in the artificial seawater, indicating that all the free $\left[{ }^{3} \mathrm{H}\right]$ leucine had been removed. Then, the specific activity per $\mathrm{ml}$ of the water in the dialysis tubes containing $\left[{ }^{3} \mathrm{H}\right]$ leucine adsorbed to $\left[{ }^{14} \mathrm{C}\right] \mathrm{CDOM}$ was assessed.

Of this water, $45 \mathrm{ml}$ was transferred to $120 \mathrm{ml}$ biological oxygen demand (BOD) bottles and inoculated with $5 \mathrm{ml}$ of $0.8 \mu \mathrm{m}$ filtered freshly collected natural bacterial consortia (concentrated -10 times, as described above) to determine the bacterial incorporation of the $\left[{ }^{14} \mathrm{C}\right] \mathrm{CDOM}$ and $\left[{ }^{3} \mathrm{H}\right]$ leucine and the respiration of the $\left[{ }^{14} \mathrm{C}\right] \mathrm{CDOM}$. Bacterial incorporation and respiration of the $\left[{ }^{14} \mathrm{C}\right]$ CDOM with $\left[{ }^{3} \mathrm{H}\right]$ leucine adsorbed was compared with the other 2 treatments to which either the same concen- 
tration of $\left[{ }^{14} \mathrm{C}\right] \mathrm{CDOM}$ or $\left[{ }^{3} \mathrm{H}\right]$ leucine was added. All 3 treatments were run in duplicate with 1 formalin-fixed control per treatment and held at $20^{\circ} \mathrm{C}$ in the dark for $8 \mathrm{~h}$. A total of 3 experiments were performed. Thereafter, bacterial abundance, incorporation and respiration were measured for each flask as described below.

Enumeration of bacteria. Formalin-fixed samples (5 $\mathrm{ml}_{i} 4 \%$ final conc.) were stained with DAPI $\left(4^{\prime}, 6\right.$ diamidino-2-phenylindole; $1 \mu \mathrm{g} \mathrm{ml}^{-1}$ final conc.) for $10 \mathrm{~min}$ (Porter \& Feig 1980) and then filtered onto a black $0.2 \mu \mathrm{m}$ pore size polycarbonate filter (Millipore; $25 \mathrm{~mm}$ filter diam) supported by a cellulose nitrate filter $(0.45 \mu \mathrm{m}$ pore size). Then, the filter was mounted on a slide and embedded in paraffin oil. Bacteria were enumerated on duplicate samples using an epifluorescence microscope (Leitz Laborlux S) at $1250 \times$ magnification. At least 300 bacteria were counted per sample. Bacterial abundance was converted to carbon biomass assuming a mean carbon content per bacterium of $20 \mathrm{fg} \mathrm{C}$ (Lee \& Fuhrman 1987).

Bacterial thymidine incorporation. Bacterial cell production was assessed by measuring the incorporation of $\left[{ }^{3} \mathrm{H}\right]$ thymidine (Amersham; SA $=85 \mathrm{Ci} \mathrm{mmol}^{-1}$, $20 \mathrm{nM}$ final conc.) (Fuhrman \& Azam 1982). Subsamples $(5 \mathrm{ml})$ were incubated in triplicate with 2 formalinkilled controls at in situ temperature in the dark for $30 \mathrm{~min}$. After incubation, the subsamples were filtered onto cellulose nitrate filters (Millipore, $0.45 \mu \mathrm{m}, 25 \mathrm{~mm}$ filter diameter) and rinsed 3 times with $5 \%$ chilled trichloroacetic acid (TCA) for 5 min. Radioactivity of these filters was assessed after adding $1 \mathrm{ml}$ ethylacetate (Rieciel-de-Haen) and $8 \mathrm{ml}$ scintillation cocktail (Insta-Gel). After allowing the samples to sit for $10 \mathrm{~h}$ in the dark, radioactivity was measured using a Packard Tri-Carb 2000 scintillation counter with the external standard ratio technique for sample quenching. $\left[{ }^{3} \mathrm{H}\right]$ Thymidine incorporation was converted into bacterial cell production by using the conversion factor of $1.1 \times 10^{18}$ cells produced mol $^{-1} \mathrm{TdR}$ (Fuhrman \& Azam 1982). Whenever the dual labeling approach was used the DPM of the samples was assessed using a dual label channel of the Tri-Carb scintillation counter.

Bacterial incorporation of non-adsorbed $\left[^{3} \mathrm{H}\right]$ leucine and dextran-adsorbed $\left[{ }^{14} \mathrm{C}\right.$ leucine. Subsamples (5 ml) were taken in triplicate over a time course of $90 \mathrm{~min}$, filtered onto cellulose nitrate filters, rinsed with $5 \%$ chilled TCA and the filters transferred to scintillation vials and ethylacetate and scintillation cocktail added as described above for the thymidine incorporation. The radioactivity of $\left[{ }^{3} \mathrm{H}\right]$ and $\left[{ }^{14} \mathrm{C}\right]$ was assessed using a dual label channel on a Tri-Carb 2000 scintillation counter. DPM were converted to fmol leucine incorporated $\mathrm{h}^{-1}$ and normalized to the bacterial abundance.

Protocol for measuring incorporation and respiration of $\left[{ }^{14} \mathrm{C}\right] \mathrm{CDOM}$ and $\left[{ }^{3} \mathrm{H}\right]$ leucine incorporation. After $8 \mathrm{~h}$, the bacterial incorporation and respiration in the $\mathrm{BOD}$ bottles was stopped by injecting $5 \mathrm{ml}$ of $6 \mathrm{~N} \mathrm{H}_{2} \mathrm{SO}_{4}$ (pH $<1.5$ ) into the $50 \mathrm{ml}$ of water with a syringe through the rubber membrane sealing the bottle. Then, $0.1 \mathrm{ml}$ of $\beta$ phenethylamine (Sigma Chemicals) was added with another syringe to the filter wick (made out of Whatman \# 1 filter) contained in a well attached to the rubber membrane. The BOD bottles were allowed to sit for $24 \mathrm{~h}$ and adsorb the respired ${ }^{14} \mathrm{CO}_{2}$ to the phenethylamine-soaked filter wick. Thereafter, the filter wick was placed in a scintillation vial and the water filtered onto cellulose nitrate filters. Generally, the same approach was used for the treatment containing only $\left[{ }^{3} \mathrm{H}\right] \mathrm{leucine}$; respiration, however, was not assessed in this treatment. All the wicks and the filters were radioassayed as described above using the dual label channel to facilitate comparison between the different treatments.

DFAA analysis. Subsamples $(10 \mathrm{ml})$ for DFAA analysis were filtered through combusted glass fiber filters $\left(480^{\circ} \mathrm{C}\right.$ for $4 \mathrm{~h}$, Whatman GF/F, $25 \mathrm{~mm}$ diameter) and kept frozen $\left(-20^{\circ} \mathrm{C}\right)$ in combusted ampoules until analysis. DFAA were measured by HPLC (MerckHitachi) using the o-phthaldialdehyde (OPA)-reverse phase chromatography method (Mopper \& Lindroth 1982). All DFAA determinations were performed in duplicate.

\section{RESULTS}

\section{Adsorption of leucine and a DFAA mixture to dextran}

Adsorption of leucine to dextran was not correlated with the molecular weight of dextran (Fig 1). A linear increase in leucine adsorbed to dextran was detected for a period of $5 \mathrm{~h}_{i}$ thereafter, no further adsorption was detectable.

Adsorption experiments were also performed with a DFAA mixture using an ultrafiltration system (molecular weight cut-off of $30 \mathrm{kDa}$ ) instead of dialysis tubes to separate non-adsorbed DFAA from dextran-adsorbed DFAA and dextran with $70 \mathrm{kDa}$. As shown in Table 1, from the originally added $748.6 \mathrm{nmol} \mathrm{l}^{-1}$ DFAA, $45.8 \%$ adsorbed to dextran within $5 \mathrm{~h}$. With 2 exceptions (glycine and threonine), all the dextran-adsorbed DFAA. species were detectable without prior hydrolysis. indicating that the binding strength of OPA (in the derivatization) is stronger than that of dextran or that different groups are involved. $100 \%$ of valine and tryptophane bound to dextran, suggesting that the originally added concentrations of these 2 DFAA species were too low to saturate adsorption or that they have different adsorption properties. Leucine adsorption $\left(6.8 \mathrm{nmol} \mathrm{\textrm {mg } ^ { - 1 }}\right.$ dextran-C) in the DFAA mixture 
Fig. 1 Development of the adsorption of $\left[{ }^{14} \mathrm{C}\right]$ leucine to dextran of various molecular sizes in artificial and aged seawater in the experimental system over time. Adsorption rates of leucine to dextran were calculated by measuring the radioactivity of leucine outside the dialysis in the surrounding water The radioactivity detected in the water in which the dialysis tubes containing dextran and leucine were suspended was subtracted from the radioactivity detected in the water in which a dialysis tube containing only leucine was suspended. For further details see text

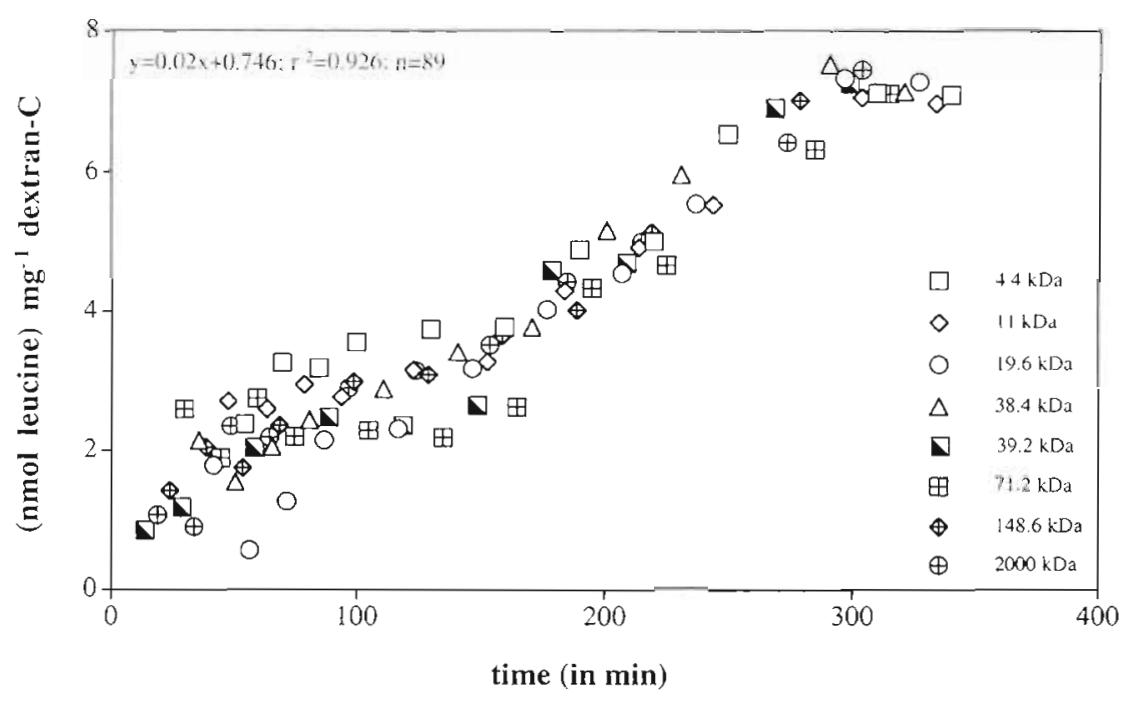

(Table 1) was exactly the same as in the time course experiment (Fig. 1) after the same incubation period of $5 \mathrm{~h}$ (based on the equation given in Fig. 1).

Table 1 Adsorption of a dissolved free amino acid (DFAA) mixture to $1 \mathrm{mg}$ dextran- $\mathrm{C} 1^{-1}(70 \mathrm{kDa})$ in 11 of artificial seawater at $20^{\circ} \mathrm{C}$ after $5 \mathrm{~h}$. DFAA adsorbed to dextran were detectable by OPA derivatization without prior hydrolysis (except glycine and threonine). Details of the experimental procedure are given in the tcxt. ASP: asparaginc; GLU: glu tamic acid; SER: serine; HIS: histidine; GLY: glycine; THR: threonine; ALA: alanine; ARG: arganine; TYR: tyrosine; MET: methionine; VAL:valine; TRY: tryptophane; PHE: phenylalanine, ILE: isoleucine; LEU: leucine; ORN: ornithine; CYS: cystine. nd: not detectable. No significant alterations in the concentration of DFAA were detectable over the incubation period in controls without dextran

\begin{tabular}{|c|c|c|c|}
\hline DFAA & $\begin{array}{l}\text { Initially added } \\
\qquad\left(\mathrm{nmol} \mathrm{l}^{-1}\right)\end{array}$ & $\begin{array}{l}\text { Adsorbed } \\
\text { (nmol l-1 and } \\
\text { nmol } \mathrm{mg}^{-1} \\
\text { dex(ran-C) }\end{array}$ & $\%$ adsorbed \\
\hline ASP & 70.7 & 34.6 & 48.9 \\
\hline GLU & 40.2 & 15.3 & 38.0 \\
\hline SER & 122.5 & 48.6 & 39.7 \\
\hline HIS & 44.3 & 14.9 & 33.6 \\
\hline GLY & 59.0 & nd & - \\
\hline THR & 32.3 & nd & - \\
\hline ALA & 50.3 & 19.0 & 37.8 \\
\hline ARG & 41.0 & 15.7 & 38.2 \\
\hline TYR & 34.3 & 12.4 & 36.0 \\
\hline MET & 45.1 & 16.7 & 37.0 \\
\hline VA.L & 23.7 & 23.7 & 100.0 \\
\hline TRY & 25.7 & 25.7 & 100.0 \\
\hline PHE & 29.9 & 9.3 & 31.0 \\
\hline ILE & 39.1 & 15.3 & 39.2 \\
\hline LEU & 20.7 & 6.8 & 33.9 \\
\hline ORN & 43.1 & 16.6 & 38.5 \\
\hline CYS & 267.0 & 9.9 & 36.7 \\
\hline Sum of DFAA & 748.6 & 284.2 & $45.8 \pm 21.6$ \\
\hline
\end{tabular}

\section{Bacterial growth on non-adsorbed leucine and dextran compared with dextran-bound leucine as substrate}

Bacterial growth in seawater cultures amended with $192 \mathrm{nmol}$ leucine either bound to $20 \mathrm{mg}$ dextran- $\mathrm{C} \mathrm{I}^{-1}$ or freely (192 nM) available resulted in about twice the bacterial abundance when grown on non-adsorbed leucine as compared to dextran-bound leucine (Fig. 2a). Dextran addition (also $20 \mathrm{mg} \mathrm{C} \mathrm{l}^{-1}$ ) to aged seawater did not promote significant growth. Bacterial production in the presence of non-adsorbed leucine was up to 3 times higher (mean: $0.76 \pm 0.08 \mu \mathrm{g} \mathrm{Cl}^{-1} \mathrm{~h}^{-1}$; $\mathrm{n}=4$ ) than at the same concentration of leucine bound to dextran (mean: $0.37 \pm 0.17 \mu \mathrm{g} \mathrm{C} \mathrm{l}^{-1} \mathrm{~h}^{-1} ; n=4$ ) (Fig. 2b). Bacterial production in the treatment amended with only dextran was more than 1 order of magnitude lower than in the other treatments (mean: $0.01 \pm 0.004 \mu \mathrm{gC} \mathrm{l}^{-1} \mathrm{~h}^{-1} ; \mathrm{n}=4$ ).

\section{Bacterial utilization of non-adsorbed versus dextran-bound leucine offered simultaneously}

In order to more directly determine the uptake of leucine in its non-adsorbed versus dextran-bound form, we simultaneously offered $\left[{ }^{14} \mathrm{C}\right]$ leucine bound to dextran and $\left[{ }^{3} \mathrm{H}\right]$ leucine at the same concentration to a natural bacterial community. As shown in Fig. 3, bacteria used non-adsorbed leucine preferentially over dextran-bound leucine. Bacterial uptake of non-adsorbed leucine was 11.7 amol bacterium ${ }^{-1} \mathrm{~h}^{-1}$ while dextranbound leucine was taken up at a 3 orders of magnitude lower rate $\left(0.11 \mathrm{amol}\right.$ bacterium $\mathrm{m}^{-1} \mathrm{~h}^{-1}$; calculated from the equations given in Fig. 3). 

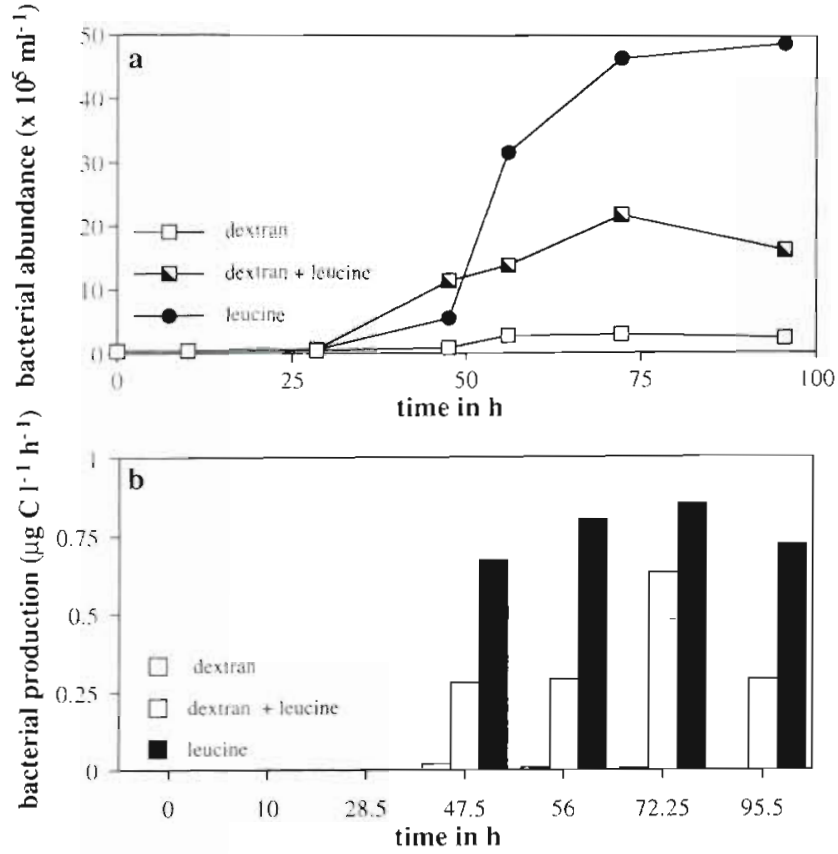

Fig. 2. Bacterial growth in seawater cultures. Aged seawater was amended either with free $20 \mathrm{mg}$ dextran $-\mathrm{Cl}^{-1}$ or $192 \mathrm{nmol}$ leucine $1^{-1}$ or in bound form (192 nmol leucine $\mathrm{I}^{-1}$ bound to $20 \mathrm{mg}$ dextran- $\mathrm{Cl}^{-1}$ ). (a) Development of bacterial abundance in the 3 different treatments over time and (b) bacterial production measured by $\left[{ }^{3} \mathrm{H}\right]$ thymidine incorporation

\section{Influence of adsorbed leucine on the utilization of phytoplankton-derived CDOM}

Additionally to dextran, phytoplankton-derived CDOM $(>1 \mathrm{kDa}$ ) was used as a model colloidal material to determine the role of adsorption of leucine on the utilization of CDOM. Leucine adsorbed to CDOM $18.75 \mathrm{nmol}$ leucine $\mathrm{mg}^{-1}$ CDOM) led, on average, to a 3 times higher incorporation rate of CDOM than CDOM without adsorbed leucine of the same concentration. The respiration rate for CDOM to which leucine was adsorbed, however, was less than half of the respiration rate of the CDOM without leucine adsorbed (Fig. 4). Total bacterial uptake (incorporation + respiration) was about twice as high for leucine-adsorbed CDOM than for CDOM without adsorbed leucine. Bacterial growth yield [bacterial production/(bacterial production + respiration) $\times 100 \mathrm{j}$ was $82 \%$ for the leucine-adsorbed CDOM and $4.0 \%$ for CDOM without leucine. Similar to the experiments above where leucine was offered simultaneously in non-adsorbed and dextran-adsorbed form (Fig. 3), incorporation of leucine was more than 20 times lower when offered in CDOM-adsorbed form (Fig. 4).

\section{DISCUSSION}

In the present study we found that amino acids efficiently adsorb to dextran and phytoplankton-derived colloidal matter. This adsorption of DFAA leads, on the one hand, to an approximately 3 times higher utilization of dextran and CDOM than of CDOM to which no amino acids are adsorbed. On the other hand, bacterial uptake of CDOM-adsorbed leucine is reduced by 2 to 3 orders of magnitude as compared to the uptake of 'truly' free leucine.

We used dialysis tubes and ultrafiltration to separate free from CDOM-adsorbed leucine and DFAA mixtures, respectively. The efficiency of this separation was checked with $\left[{ }^{14} \mathrm{C}\right.$ jdextran of $70 \mathrm{kDa}$. Loss of dextran through the dialysis tubes (molecular weight cut off $1 \mathrm{kDa}$ ) was found to be less than $2 \%$ while ultrafiltration ( $30 \mathrm{kDa}$ molecular weight cut off) resulted in a loss of $-8 \%$. Thus the DFAA concentrations given in Table 1 are likely to slightly underestimate adsorption, since no attempts were made to correct the leucine concentrations measured for potential dextran loss through the cartridge. Nevertheless, the error introduced due to inefficient retention by the dialysis tubes and the ultrafiltration cartridge is probably small and does not alter the general conclusions from these experiments. Data obtained from leucine adsorption using dialysis tubes (Fig. 1) agreed well with the leucine adsorption in the DFAA mixture experiment

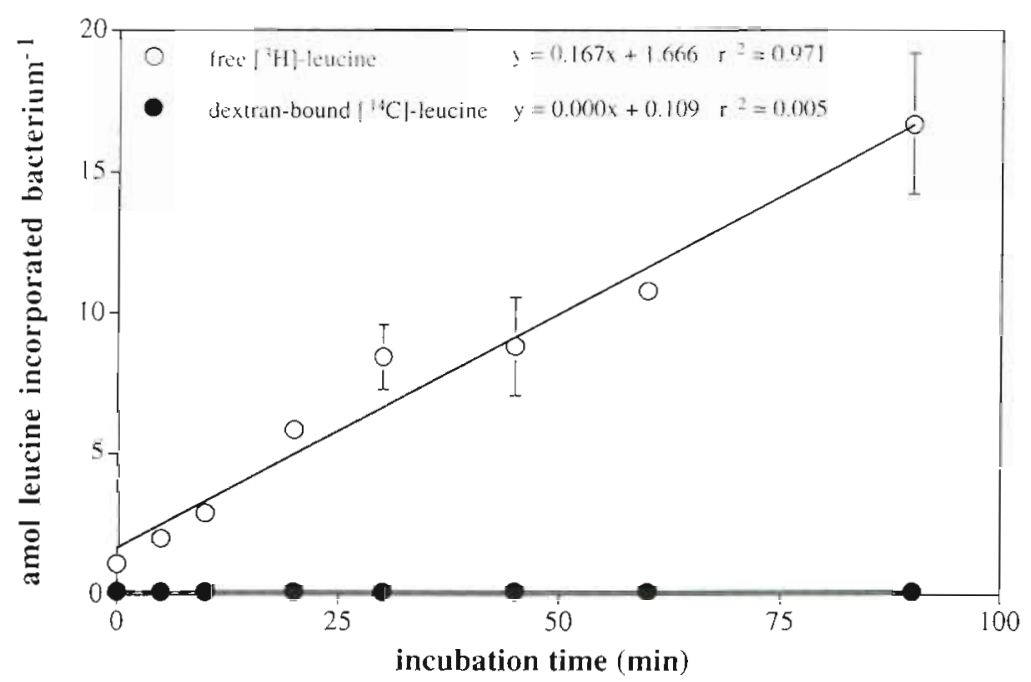

Fig. 3. Time course of bacterial incorporation of leucine offered simultaneously in the same concentration $\left(9.6 \mathrm{nmol} \mathrm{\textrm {m } ^ { - 1 }}\right)$ in free $\left(\left[{ }^{3} \mathrm{H}\right]\right.$ leucine $)$ and in dextran-bound $\left({ }^{1 / 4} \mathrm{C}\right.$ leucine $)$ form; amol $=10^{-18} \mathrm{~mol}$ 


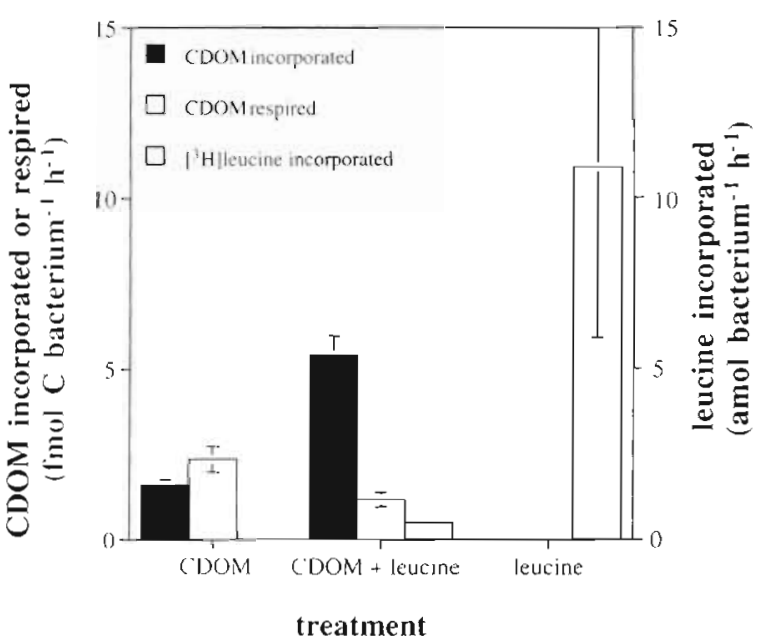

Fig. 4. Bacterial incorporation and respiration of phytoplankton-derived colloidal DOM (CDOM; $16.8 \mathrm{mg} \mathrm{Cl}^{-1}$ or $1.4 \mathrm{mmol}$ $\mathrm{C}^{-1}$ ) in the presence and absence of adsorbed leucine (147 nmol $\mathrm{l}^{-1}$, corresponding to $8.75 \mathrm{nmol}$ leucine $\mathrm{mg}^{-1}$ CDOM) and, for comparison, the uptake of free leucine (147 $\mathrm{nmol} \mathrm{l}^{-1}$ ) in the absence of phytoplankton-derived CDOM. Bars represent means \pm SD of 3 experiments each performed in duplicate. Note that the incorporation and respiration of CDOM is in fmol $\mathrm{C}$ bacterium ${ }^{-1} \mathrm{~h}^{-1}$ while the leucine incorporation is given in amol bacterium ${ }^{-1} \mathrm{~h}^{-1}\left(\mathrm{amol}=10^{-18} \mathrm{~mol}\right)$

using ultrafiltration (Table 1) further indicating that both methods give comparable results.

Using dextran and phytoplankton-derived CDOM as model colloids and leucine as a model substance which is readily utilizable for bacterioplankton we determined the importance of adsorption processes on the utilization of CDOM. DFAA readily adsorb to CDOM as shown in Fig. 1 and Table 1. The adsorbed leucine, however, is barely utilized if non-adsorbed leucine is available as well (Fig. 3). If DFAA are available in their free, non-adsorbed form then they are preferentially used. Similar results were obtained for phytoplanktonderived CDOM (Fig. 4), indicating that dextran serves as a good model to study the adsorption of labile components and its influence on the utilization of CDOM by marine bacterioplankton.

Our results indicate that under in situ conditions, CDOM, owing to its adsorptive capacity, competes with bacterioplankton for 'free' DFAA. Since polysaccharides have been shown to be the dominant chemically characterizable compound of the oceanic DOM pool (Benner et al. 1992, Pakulski \& Benner 1994, McCarthy et al. 1996, Aluwihare et al. 1997), this competition between abiotic adsorption and bacterioplankton uptake might be of considerable biogeochemical significance. Nagata \& Kirchman (1996) calculated the surface area of colloids to be in the range of $10 \mathrm{~m}^{2} \mathrm{~m}^{-3}$ (derived from data given in Koike et al. 1990 and Wells \& Goldberg 1991) in the upper mixed layer of the ocean. Similar to our findings, Nagata \& Kirchman (1996) found lower utilization rates of proteins (bovine serum albumin, BSA) adsorbed to sub-micrometer particles. Due to its smaller size, the surface area of CDOM used in this study probably exceeds the surface area calculated by Nagata \& Kirchman (1996). This implies that, for a DFAA molecule released from a source such as a phytoplankton cell, it is much more likely to become adsorbed to a CDOM molecule than get in contact with bacteria due to the at least 4 orders of magnitude lower numbers and even lower surface area of bacteria. The concentration of single DFAA species in oceanic waters is usually in the range of 5 to $50 \mathrm{nM}$, depending on the amino acid species and the trophic stage of the water body (Mopper \& Lindroth 1982, Sondergaard et al. 1985, Fuhrman \& Ferguson 1986, Keil \& Kirchman 1991a, Müller-Niklas et al. 1994). The extent to which these DFAA concentrations are really free in the pelagic environment remains unknown since the OPA derivatization technique to detect DFAA does not distinguish between truly free (non-adsorbed) and adsorbed DFAA, as shown in Table 1. Jorgensen \& Sondergaard (1984) conducted size exclusion chromatography to determine the molecular weight structure of the DFAA detected by OPA derivatization and HPLC and concluded that most of the DFAA are truly free and not adsorbed. Our study, however, points to the possibility of efficient adsorption of DFAA to CDOM and thereby significantly reducing the availability of these adsorbed DFAA for bacteria. Due to adsorption of highly labile DFAA to refractory CDOM, the CDOM-DFAA complex becomes 'semi-labile' and therefore more easily degradable (Figs. 2 \& 4).

Oceanic dissolved organic carbon (DOC) concentrations range from $\sim 100 \mu \mathrm{M}$ in surface waters to $\sim 45 \mu \mathrm{M}$ in the deep ocean, and about 10 to $50 \%$ of this DOC pool is considered as colloidal DOC (Kepkay et al. 1993, Guo et al. 1994). The major fraction of this colloidal DOC is comprised of polysaccharides (Benner et al. 1992). Thus in surface waters, colloidal DOC is present in concentrations between $\sim 8$ and $\sim 40 \mu \mathrm{M}$ (100 to $480 \mu \mathrm{g} \mathrm{C} \mathrm{l}^{-1}$ ). Based on the mean adsorption of DFAA to dextran of $284 \mathrm{nmol}$ DFAA $\mathrm{mg}^{-1}$ dextran-C (Table 1), between 28 and 136 nmol DFAA could be adsorbed to colloidal DOC in oceanic surface waters, assuming that this colloidal DOC has the same adsorption capacity as dextran and phytoplankton-derived CDOM used in this study. Typically, the sum of DFAA in the ocean ranges between 70 and $100 \mathrm{nM}$ (Suttle et al. 1991). This would mean that between $\sim 11$ and $55 \%$ of the DFAA detectable by HPLC can be adsorbed to CDOM in surface waters.

The finding that DFAA adsorb efficiently to CDOM, and, as a consequence, CDOM-adsorbed DFAA are 


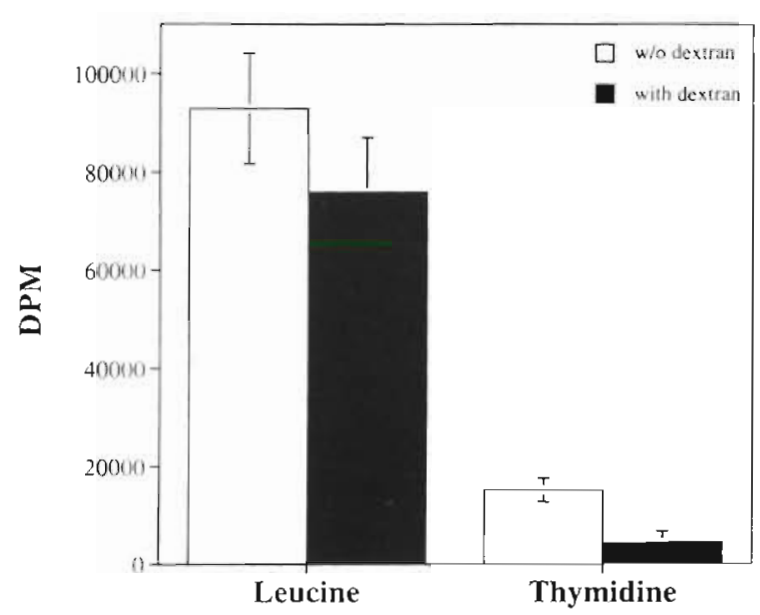

Fig. 5. Effect of dextran addition (1 $\mathrm{mg}$ dextran-C $\mathrm{l}^{-1}$ final conc.) on bacterial thymidine or leucine incorporation using $20 \mathrm{nM}$ of either $\left[{ }^{3} \mathrm{H}\right]$ leucine or $\left[{ }^{3} \mathrm{H}\right]$ thymidine (final conc.) and freshly collected seawater from the NIOZ pier (Marsdiep, The Netherlands, coastal North Sea). Samples were incubated in triplicate with 2 formalin-killed blanks for $30 \mathrm{~min}$ in the dark. Vertical lines represent the SD from the mean of 3 replicate measurements. The difference between the leucine incorporation to which dextran was added and the treatment to which no dextran was added was not significant (Mann-Whitney, $p=$ 0.127 ); significant differences were detectable between the 2 different treatments for the thymidine incorporation (MannWhitney, $\mathrm{p}=0.049 \mathrm{j}$. DPM: disintegrations per minute

incorporated into bacteria at a significantly lower rate, also has important implications for bacterial production measurements. The most commonly used methods for bacterial production measurements are the incorporation of radiolabeled thymidine into bacterial DNA and leucine into bacterial protein (Kemp et al. 1993). In a preliminary experiment to test the presence of CDOM on bacterial production measurements, we added $20 \mathrm{nM}\left[{ }^{3} \mathrm{H}\right]$ leucine or $\left[{ }^{3} \mathrm{H}\right]$ thymidine, respectively, to $1 \mathrm{mg}$ dextran- $\mathrm{Cl}^{-1}$ (all final conc. in $5 \mathrm{ml}$ subsamples) and compared the incorporation rates with those obtained by adding $20 \mathrm{nM}$ of leucine or thymidine only. The presence of $1 \mathrm{mg}$ dextran-C $\mathrm{l}^{-1}$ significantly reduced the bacterial incorporation of radiolabeled leucine and thymidine (Fig. 5). The effect of tracer adsorption to dextran was much more pronounced for thymidine than for leucine, leading to underestimation of the actual bacterial production. Tracer adsorption to CDOM might bias bacterial production measurements, especially in environments with high concentrations of CDOM such as in marine snow. In fact, the polysaccharidic matrix of marine snow efficiently binds radiolabeled thymidine as well as leucine added for bacterial production measurements (Herndl unpubl. data). Discrepancies have been found in marine snow between bacterial growth measured by thymidine and leucine uptake and ectoenzymatic activity (Karner \& Herndl 1992. Smith et al. 1992). In both studies it was concluded that ectoenzymatic activity on marine snow is higher than the demand for macromolecular synthesis to sustain the measured bacterial growth. As shown in Fig 3, if all possible adsorption sites are occupied, substrate addition leads to a linear increase over time. This saturation of possible adsorption sites has to be tested before bacterial production measurements are performed on marine snow, although this is often difficult in practice due to the limited number of samples available.

The biogeochemical implication of the finding that DFAA efficiently adsorbs to refractory CDOM is that CDOM becomes more accessible to bacterial degradation. The number of colloidal particles has been shown to rapidly decline with depth, indicating that most of the colloids are decomposed in the euphotic zone (Koike et al. 1990, Wells \& Goldberg 1991, 1994). Based on our data, adsorption of labile, freshly released DFAA by phytoplankton or via sloppy feeding of zooplankton on phytoplankton (Lampert 1978, Riemann et al. 1986) might be responsible for the observed rapid decline of colloids in the upper layers of the ocean and thereby reduce the amount of CDOM transferred into the deeper layers. Upon adsorption of labile DFAA to CDOM, this high molecular weight CDOM is more efficiently utilized by bacteria, shifting, ultimately, the size spectrum of the oceanic DOM towards low molecular weight DOM, which has been shown to be comparatively old (Guo et al. 1996) and utilized by bacterioplankton at low rates (Amon \& Benner 1996)

In summary, we have shown that DFAA readily adsorb to CDOM and particularly to polysaccharides, and thereby making them more easily available for bacterioplankton utilization while reducing the availablility of the adsorbed compared to non-adsorbed DFAA by orders of magnitude. This finding also has implications for bacterial production measurements, since the underlying assumption of these measurements is that the added tracer is taken up at the same rate as the unlabeled molecules present in the water Since an unknown amount of tracer might adsorb to CDOM, this assumption might be violated. This might be of particular relevance in situations where colloidal matter is abundant, such as in marine snow, and if high colloidal matter environments are compared with low colloidal matter environments, such as surface versus deep water Clearly, more awareness of this potential problem is necessary and more emphasis has to be put on the abiotic interactions of molecules and the influence of these interactions on bacterial. transformation of DOM in the ocean. 
Acknowledgements. Financial support was provided by the Austrian Science Foundation (FWF-grants \# 9388 and 10974) to G.J.H. and by the Commission of the European Community (Contract \# MAS2-CT94-0090). J.M.A. was supported by a TMR grant of the European Community (MAS3-CT96-5004). This work is in partial fulfillment of the requirements for a Ph.D. degree from the University of Vienna by S.S. This is publication 3289 of NIOZ.

\section{LITERATURE CITED}

Aluwihare LI, Repeta DJ, Chen RF (1997) A major biopolymeric component to dissolved organic carbon in surface water. Nature 387:166-169

Amon RMW, Benner R (1994) Rapid cycling of high-molecular-weight dissolved organic matter in the ocean. Nature 369: $549-552$

Amon RMW, Benner R (1996) Bacterial utilization of different size classes of dissolved organic matter. Limnol Oceanogr 41:41-51

Azam F, Cho BC (1987) Bacterial utilization of organic matter in the sea. In: Fletcher M, Gray TRG, Jones JG (eds) Ecology of microbıal communities. Cambridge University Press, Cambridge, p 261-281

Baskaran M, Santschi PH (1993) The role of particles and colloid in the transport of radionuclides in coastal environ. ments of Texas. Mar Chem 43:95-114

Benner R, Pakulski JD, McCarthy M, Hedges JI, Hatcher PG (1992) Bulk chemical characteristics of dissolved organic matter in the ocean. Science 255:1561-1564

Ducklow HW, Kirchman DL, Quinby HL, Carlson CA, Dam HG (1993) Stocks and dynamics of bacterioplankton carbon during the spring bloom in the eastern North Atlantic Ocean. Deep Sea Res 11:245-263

Fuhrman $J$ (1987) Close coupling between release and uptake of dissolved free amino acids in seawater studied by an isotope dilution approach. Mar Ecol Prog Ser 37:45-52

Fuhrman JA, Azam F (1982) Thymidine incorporation as a measure of heterotrophic bacterioplankton production in marine surface waters: evaluation and field results. Mar Biol 66:109-120

Fuhrman JA, Ferguson RL (1986) Nanomolar concentrations and rapid turnover of dissolved free amino acids in seawater: agreement between chemical and microbiological measurements. Mar Ecol Prog Ser 33:237-242

Gottschalk G (1986) Bacterial metabolism. Springer-Verlag, New York

Granéli W, Lindell M, Tranvik L (1996) Photo-oxidative production of dissolved inorganic carbon in lakes of different humic content. Limnol Oceanogr 41:698-706

Guo L, Coleman CH Jr, Santschi PH (1994) The distribution of colloidal and dissolved organic carbon in the Gulf of Mexico. Mar Chem 45:105-119

Guo L, Santschi PH, Cifuentes LA, Trumbore SE, Southon J (1996) Cycling of high-molecular-weight dissolved organic matter in the Middle Atlantic Bight as revealed by carbon isotopic $\left({ }^{13} \mathrm{C}\right.$ and $\left.{ }^{14} \mathrm{C}\right)$ signatures. Limnol Oceanogr 41:1242-1252

Gustafsson Ö, Gschwend PM (1997) Aquatic colloids: concepts, defintions, and current challenges. Limnol Oceanogr 42: $519-528$

Hedges JI, Keil RG (1995) Sedimentary organic matter preservation: an assessment and speculative synthesis. Mar Chem 49:81-115

Heissenberger A, Herndl GJ (1994) Formation of high molecular weight material by free-living marine bacteria. Mar
Ecol Prog Ser 111:129-135

Herndl GJ, Kaltenböck E, Müller-Niklas G (1993) Dialysis bag incubation as a non-radiolabeling technique to estimate bacterial production. In: Kemp PF, Sherr BF, Sherr EB, Cole JJ (eds) Handbook of methods in aquatic microbial ecology. Lewis Publishers, Boca Raton, p 553-556

Jørgensen NOG (1987) Free amino acids in lakes: concentrations and assimilation rates in relation to phytoplankton and bacterial production. Limnol Oceanogr 32:97-111

Jørgensen NOG, Kroer N, Coffin RB, Yang XH, Lee C (1993) Dissolved free amino acids, combined amino acids, and DNA as sources of carbon and nitrogen to marine bacteria. Mar Ecol Prog Ser 98:135-148

Jørgensen NOG, Søndergaard M (1984) Are dissolved free amino acids free? Microb Ecol 10:301-316

Kaiser E, Herndl GJ (1997) Rapid recovery of marine bacterioplankton activity after inhibition by UV radiation in coastal waters. Appl Environ Microbiol 63:4026-4031

Karner M, Herndl GJ (1992) Extracellular enzymatic activity and secondary production in free-living and marine snow associated bacteria. Mar Biol 113:341-347

Keil RG, Kirchman DL (1991a) Contribution of dissolved free amino acids and ammonium to the nitrogen requirements of heterotrophic bacterioplankton. Mar Ecol Prog Ser 73:1-10

Keil RG, Kirchman DL (1991b) Dissolved combined amino acids in marine waters as determined by a vapor-phase hydrolysis method. Mar Chem 33:243-259

Keil RG, Kirchman DL (1993) Dissolved combined amino acids: chemical form and utilization by marine bacteria. Limnol Oceanogr 38:1256-1270

Keil RG, Kirchman DL (1994) Abiotic transformation of labile protein to refractory protein in sea water. Mar Chem 45: $187-196$

Keil RC. Montluçon DB. Prahl FG, Hedqes JI (1994) Sorptive preservation of labile organic matter in marine sediments. Nature 370:549-552

Kemp PF, Sherr BF, Sherr EB, Cole JJ (1993) Handbook of methods in aquatic microbial ecology. Lewis Publishers, Boca Raton

Kepkay PE (1994) Particle aggregation and the biological reactivity of colloids. Mar Ecol Prog Ser 109:293-304

Kepkay PE, Niven SEH, Milligan TG (1993) Low molecular weight and colloidal DOC production during a phytoplankton bloom. Mar Ecol Prog Ser 100:233-244

Kirchman DL, Keil RG, Simon M, Welschmeyer NA (1993) Biomass and production of heterotrophic bacterioplankton in the oceanic subarctic Pacific. Deep Sea Res 40:967-988

Koike I, Hara S, Terauchi K, Kogure K (1990) Role of submicrometre particles in the ocean. Nature 345:242-244

Lampert W (1978) Release of dissolved organic carbon by grazing zooplankton. Limnol Oceanogr 23:831-834

Lee S, Fuhrman JA (1987) Relationships between biovolume and biomass of naturally derived marine bacterioplankton. Appl Environ Microbiol 53:1298-1303

Lindell MJ, Granéli W, Tranvik LJ (1995) Enhanced bacterial growth in response to photochemical transformation of dissolved organic matter. Limnol Oceanogr 40:195-199

Lindell MJ, Granéli HW, Tranvik IJ (1996) Effects of sunlight on bacterial growth in lakes of different humic content. Aquat Microb Ecol 11:135-141

Martin JM, Dai MH, Cauwet G (1995) Significance of colloids in the biogeochemical cycling of organic carbon and trace metals in the Venice Lagoon (Italy). Limnol Oceanogr 40: $119-131$

McCarthy M, Hedges J, Benner R (1996) Major biochemical composition of dissolved high molecular weight organic matter in seawater. Mar Chem 55:281-297 
Middelboe M, Borch NH, Kirchman DL (1995) Bacterial utilization of dissolved free amino acids, dissolved combined amino acids and ammonium in the Delaware Bay estuary: effects of carbon and nitrogen limitation. Mar Ecol Prog Ser 128:109-120

Mopper K, Lindroth P (1982) Diel and depth variations in dissolved free amino acids and ammonium in the Baltic Sea determined by shipboard HPLC analysis. Limnol Oceanogr 27:336-347

Moran SB, Yeats PA, Balls PW (1996) On the role of colloids in trace metal solid-solution partitioning in continental shelf waters: a comparison of model results and field data. Cont Shelf Res 16:397-408

Müller-Niklas G, Schuster S, Kaltenböck E, Herndl GJ (1994) Organic content and bacterial metabolism in amorphous aggregations of the northern Adriatic Sea. Limnol Oceanogr 39:58-68

Nagata T, Kirchman DL (1996) Bacterial degradation of protein adsorbed to model submicron particles in seawater Mar Ecol Prog Ser 132:241-248

Pakulski JD, Benner R (1994) Abundance and distribution of carbohydrates in the ocean. Limnol Oceanogr 39:930-940

Parsons T, Maita Y, Lalli C (1984) A manual of chemical and biological methods for seawater analysis. Pergamon Press, Oxford

Porter KG, Feig YS (1980) The use of DAPI for identifying and counting aquatic microflora. Limnol Oceanogr 25:943-948

Reitner B, Herzig A, Herndl GJ (1997) Role of ultraviolet-B radiation on photochemical and microbial oxygen consumption in a humic-rich shallow lake. Limnol Oceanogr 42:950-960

Rich JH, Ducklow HW, Kirchman DL (1996) Concentrations and uptake of neutral monosaccharides along $140^{\circ} \mathrm{W}$ in the equatorial Pacific: contribution of glucose to heterotrophic bacterial activity and the DOM flux. Limnol Oceanogr 41:595-604

Riemann B, Jørgensen NOG, Lampert W, Fuhrman JA (1986)

Editorial responsibility: Otto Kinne (Editor)

Oldendorf/Luhe, Germany
Zooplankton induced changes in dissolved free amino acids and in production rates of freshwater bacteria. Microb Ecol 12:247-258

Sherr EB (1988) Direct use of high molecular weight polysacchande by heterotrophic flagellates. Nature 335:348-351

Smith DC, Simon M, Alldredge AL, Azam F (1992) Intense hydrolytic enzyme activity on marine aggregates and implications for rapid particle dissolution. Nature 359: $139-142$

Sondergaard M, Riemann B, Jørgensen NOG (1985) Extracellular organic carbon (EOC) released by phytoplankton and bacterial production. Oikos 45:323-332

Stoderegger K, Herndl GJ (in press) Production and release of bacterial capsular material and its subsequent utilization by marine bacterioplankton. Limnol Oceanogr

Suttle CA, Chan AM, Fuhrman JA (1991) Dissolved free amino acids in the Sargasso Sea: uptake and respiration rates, turnover times, and concentration. Mar Ecol Prog Ser 70:189-199

Tranvik LJ (1993) Microbial transformation of labile dissolved organic matter into humic-like matter in seawater. FEMS Microbiol Ecol 12:177-183

Tranvik LJ (1994) Colloidal and dissolved organic matter excreted by a mixotrophic flagellate during bacterivory and autotrophy. Appl Environ Microbiol 60:1884-1888

Veronclark RN, Goldberg ED, Bertine KK (1995) Organic and inorganic characterization of marine colloids. Chem Ecol 11:69-83

Wells ML, Goldberg ED (1991) Occurrence of small colloids in sea water. Nature 353:342-344

Wells ML, Goldberg ED (1994) The distribution of colloids in the North Atlantic and Southern Oceans. Limnol Oceanogr 39:286-302

Wetzel RG, Hatcher PG, Bianchi TS (1995) Natural photolysis by ultraviolet irradiance of recalcitrant dissolved organic matter to simple substrates for rapid bacterial metabolism. Limnol Oceanogr 40:1369-1380

Submitted: October 8, 1997; Accepted: March 30, 1998 Proofs received from author(s): April 29, 1998 